DARIA HeJWOSZ-GromKOWSKA

ORCID 0000-0003-2144-9600

Uniwersytet im. Adama Mickiewicza

$w$ Poznaniu

\title{
KAPITAŁ I ZAUFANIE SPOŁECZNE A AKTYWNOŚĆ OBYWATELSKA W ANGLII I POLSCE - IMPLIKACJE DLA EDUKACJI OBYWATELSKIEJ
}

\begin{abstract}
Aвstract. Hejwosz-Gromkowska Daria, Kapitat i zaufanie społeczne a aktywność obywatelska w Anglii $i$ Polsce - implikacje dla edukacji obywatelskiej [Capital and Social Trust vs. Active Citizenship in England and Poland - Implications for Civic Education]. Studia Edukacyjne nr 56, 2020, Poznań 2020, pp. 85-109. Adam Mickiewicz University Press. ISSN 1233-6688. DOI: 10.14746/se.2020.56.5

The aim of the paper is to analyze the tendencies of shaping both social capital and social trust in England and Poland. The analyses of aforementioned categories allow to explain the patterns of conventional civic participation. The social capital and social trust are also important factors influencing citizenship education. Therefore, analysis comprises policies towards citizenship education in English and Polish schools.
\end{abstract}

Key words: citizenship education, England, Poland, social capital, social trust

W niniejszej pracy podejmę próbę zarysowania tendencji w kształtowaniu kapitału i zaufania społecznego w Anglii i Polsce w kontekście konwencjonalnej aktywności obywatelskiej. Z tak obranej perspektywy zostaną również przeanalizowane propozycje i rozwiązania dla edukacji obywatelskiej. Zaufanie społeczne stanowi istotną część kapitału społecznego. Znajomość i eksploracja zagadnień związanych z omawianymi kategoriami pozwala na udzielenie odpowiedzi między innymi na następujące pytanie: dlaczego $w$ jednych społeczeństwach ludzie nie zamykają domów na klucz, a w innych oddzielają od sąsiadów. W społeczeństwach $\mathrm{z}$ „otwartymi domami” istnieje większe zaufanie społeczne, a badania wskazują, że wiąże się ono z wyższym kapitałem społecznym. Istnieje także zależność między wykształceniem a kapitałem społecznym - im jest ono wyższe, tym wyższy kapitał. Odwoływanie się do przywołanej kategorii pozwala także zrozumieć, dlaczego w jednych społeczeństwach aktywność i zaangażowanie obywateli jest duże, a w innych znikome. 


\section{Zaufanie społeczne jako element kapitału społecznego}

Wyłonienie społeczeństwa postindustrialnego (Touraine, Bell) zaowocowało pojawieniem się, zdaniem niektórych badaczy, orientacji indywidualistycznej we współczesnych społeczeństwach. Przedmiotem dociekań socjologów - a wcześniej filozofów - były siły, które scalają jednostki i motywują je do kolektywnego działania. Emil Durkheim w swych pracach podejmował problem społecznej i moralnej solidarności, jako ogniw spajających społeczeństwo i przeciwdziałających społecznej anomii ${ }^{1}$. O ogniwach sprzyjających rozwojowi demokracji pisał też Alexis de Tocqueville. Przypisywał on duże znaczenie działalności stowarzyszeń i organizacji w amerykańskim społeczeństwie, które miały przeciwdziałać nadmiernej indywidualizacji jednostek ${ }^{2}$. Kolejne pokolenia obserwatorów i badaczy życia społecznego starają się opisać siły, które przeciwdziałają rozpadowi społeczeństwa. Świat społeczny, podobnie jak świat przyrody, nie składa się jedynie z wolnych atomów, które funkcjonują niezależnie od siebie, pogrążając się w chaosie. Przeciwnie, jednostki ludzkie, tak jak atomy, będą dążyły do tworzenia związków, struktur, konglomeratów, a zatem - do opanowania chaosu i dążenia do stabilizacji społecznej. W strukturze społecznej jednostki wchodzą w interakcje i współpracę. Dzieje się tak w codziennych praktykach społecznych, które przenoszą się także ze szczebla mikrospołecznego na makrospołeczny. W ostatnich dekadach kategorią, która zostaje wykorzystana do operacjonalizacji więzi społecznych jest kapitał społeczny. Stanowi on ważną kategorię teoretyczną $\mathrm{w}$ analizie problematyki edukacji obywatelskiej. Liczne badania pokazują, że poziom wykształcenia społeczeństwa wpływa na budowanie więzi społecznych, status materialny, zadowolenie z życia oraz możliwości samorealizacji. Kapitał społeczny jest częścią kapitału ludzkiego, która istnieje niezależnie od „,wieku, pozycji i poziomu umysłowego" ${ }^{3}$. To właśnie od kapitału społecznego, w który wyposażona jest jednostka, zależy gotowość do angażowania się, poczucie sprawiedliwości oraz poziom zaufania wobec innych osób czy instytucji społecznych ${ }^{4}$. Kapitał społeczny stał się przedmiotem badań różnych dyscyplin naukowych - medycyny, kryminologii, ekonomii, socjologii, politologii - bowiem przypisuje się mu coraz większe znaczenie w funkcjonowaniu jednostek w różnych sferach życia społecznego. W latach osiemdziesiątych XX wieku na-

\footnotetext{
${ }^{1}$ Zob. E. Durkheim, O podziale pracy społecznej, Warszawa 2019.

${ }^{2}$ Zob. A. De Tocqueville, O demokracji w Ameryce, Warszawa 2005.

${ }^{3}$ K. Przyszczypkowski, Edukacja dla demokracji. Strategie zmian a kompetencje obywatelskie, Poznań - Toruń 1999, s. 30.

${ }^{4}$ W. Kymlicka, Contemporary political philosophy. An Introduction, Oxford 2002, s. 286.
} 
stąpiło ożywienie w badaniu tej kategorii zarówno w Europie, jak i Stanach Zjednoczonych. W europejskiej myśli socjologicznej koncepcję tę rozwinął między innymi Pierre Bourdieu, który zauważył, że w celu szerszego zrozumienia funkcjonowania społeczeństwa konieczna jest analiza kapitałów: ekonomicznego, kulturowego i społecznego ${ }^{5}$. Natomiast, w Stanach Zjednoczonych problematykę kapitału pod koniec lat osiemdziesiątych rozwinął James S. Coleman, który zdefiniował go, jako „normy, społeczną sieć, oraz relację między dorosłymi a dziećmi, które stanowią wartość w wychowaniu dzieci" ${ }^{\prime}$. Jednak jednym z najbardziej znanych badaczy kapitału społecznego jest Amerykanin Robert Putnam. Jego badania prowadzone we Włoszech, a później w Stanach Zjednoczonych stały się inspiracją do dalszych dociekań nad znaczeniem omawianej kategorii. Przywołany badacz zauważa, że charakterystycznymi cechami sieci społecznej są aktywność i lojalność obywateli wobec siebie, a także szczerość i altruizm. Pobudzają one do aktywnego działania, gdyż legitymizują zasadę wzajemności - ludzie są przekonani, że jeżeli uczynią coś dla innych, prawdopodobnie inni uczynią coś dla nich. Poczucie wzajemności, zaufania oraz szczerości są - dla przywołanego teoretyka - elementami, które wpływają łagodząco na społeczeństwo. Jeśli kapitał społeczny jest wysoki, wówczas lokalne społeczności stają się „przyjemnymi miejscami do życia"7

Kapitał społeczny pozwala obywatelom na wspólne rozwiązywanie problemów. Wpływa również na poziom zaufania, gdyż im obywatele wykazują większy jego stopień wobec siebie, tym lepiej rozwijają się społeczności, w których żyją. Ponadto, ci którzy przejawiają wyższy kapitał społeczny, mają lepsze relacje z innymi ludźmi, stają się „bardziej tolerancyjni, mniej cyniczni oraz bardziej empatyczni na nieszczęścia innych" ${ }^{\prime \prime}$.

Kapitał społeczny oznacza sieć powiązań, normy postępowań oraz sankcje społeczne, które ułatwiają sprawne działanie jednostek i grup społecznych. Dwa rodzaje kapitału - wiążący/spajający (bonding) i pomostowy (bridging) zostały wprowadzone do socjologii przez Roberta Putnama. Ten pierwszy ma charakter inkluzyjny, dotyczy więzi występujących w jednej grupie społecznej, na przykład w rodzinie czy sąsiedztwie. Natomiast pomostowy kapitał występuje pomiędzy ludźmi należącymi do różnych grup społecznych ${ }^{9}$. Badania pokazują, iż przedstawiciele klasy średniej wykazują większy kapi-

${ }^{5}$ P. Bourdieu, Reprodukcja, Warszawa 2012.

${ }^{6}$ R.D. Putnam, Community based social capital and educational performance, [w:] Making good citizens. Education and civil society, red. D. Ravitch, J.P. Viteritti, New Haven - London 2001, s. 58.

7 Tamże, s. 60.

${ }^{8}$ R.D. Putnam, Bowling alone. The collapse and revival of American community, New York 2000, s. 288.

9 Tamże, s. 359. 
tał pomostowy niż przedstawiciele klas robotniczych, dlatego też możliwości osiągania przez nich sukcesu życiowego są relatywnie większe ${ }^{10}$.

Na poziomie mezo omawiana kategoria kształtowana jest w szkole oraz społeczności lokalnej. Odwołując się do badań Jamesa Colemana, warto zauważyć, iż dzieci uczęszczające do katolickich szkół w USA osiągały lepsze efekty, rzadziej porzucały przedwcześnie naukę niż te, które uczęszczały do szkół publicznych ${ }^{11}$. Podobny efekt zaobserwowano w przypadku małych szkół. Badacze przedmiotu przypisują duże znaczenie angażowaniu się rodziców w życie szkoły oraz tworzeniu lepszych więzi między rodzicami. Obserwuje się również pozytywną korelację między relacjami w środowisku lokalnym (poczucie wspólnotowości) a realizowaniem zadań szkoły. Istnieją również dowody, wskazujące na znaczenie kapitału społecznego wewnątrz szkoły, a zatem na relacje występujące między nauczycielami i zwierzchnikami. Jednak, jak zauważa David Halpern, znaczenie więzi w społeczności lokalnej odgrywa znaczącą rolę w działalności szkół. Wysoka koncentracja niskiego kapitału społecznego w rodzinach mieszkających na danym terenie powoduje gorsze osiągnięcia szkolne w całej tamtejszej populacji. Co więcej, niski kapitał społeczny społeczności lokalnej powoduje, że jednostki mają słabsze osiągnięcia edukacyjne, co zostało nazwane efektem podwójnego zagrożenia (wykluczenia) ${ }^{12}$. Nic więc dziwnego, iż w ostatnich latach wiele uwagi skupia się na wzmocnieniu kapitału społecznego w społecznościach lokalnych, poprzez wzajemną współpracę środowiska szkolnego i lokalnego, co można zaobserwować w strategiach dla edukacji obywatelskiej w Anglii, jak również w postulatach badaczy polskich ${ }^{13}$.

Badania przywołanego wcześniej Putnama przeprowadzone w Stanach Zjednoczonych dowodzą, że im wyższy kapitał społeczny, tym lepsze osiągnięcia edukacyjne. W stanach, w których wyniki w nauczaniu były wyższe, wyższa również była aktywność obywateli. Ponadto, tam, gdzie występował większy odsetek mniejszości rasowych, grup o niższym przychodzie oraz niepełnych rodzin, wyniki w nauczaniu również były gorsze ${ }^{14}$. W opinii Putnama niezwykle istotny jest kapitał społeczny kumulowany w danej społeczności, jako jeden z czynników wpływających na poziom edukacji. Czynniki kształtujące społeczny kapitał wiążą się z rasą, strukturą rodziny, przycho-

${ }^{10}$ D. Halpern, Social capital, Cambridge 2014, s. 23.

11 Tamże, s. 167.

${ }^{12}$ Tamże, s. 168.

${ }^{13}$ Zob. m.in. A. Szczurek-Boruta, Stałość i zmienność. Poczucie tożsamości narodowej młodzieży i nowy wymiar edukacji obywatelskiej, [w:] Etniczność i obywatelskość w nowej Europie. Konteksty edukacji międzykulturowej, red. J. Nikitorowicz, D. Misiejuk, M. Sobecki, Białystok 2007; E. Wnuk-Lipiński, Socjologia życia publicznego, Warszawa 2008 oraz diagnozy społeczne pod redakcją J. Czapińskiego.

${ }^{14}$ R.D. Putnman, Community based social capital, s. 71. 
dem, klasą społeczną. W świetle powyższych poglądów można zauważyć, że kapitał społeczny odgrywa znaczącą rolę w osiągnięciach edukacyjnych. Tym samym, przeciwdziała on wykluczeniu społecznemu. Jeśli obywatele są wykształceni, zaangażowani w społeczność lokalną, ale także globalną, ich status społeczny jest wyższy.

Dla Colemana najważniejszy dla osiągnięć edukacyjnych jednostki był rodzinny kapitał społeczny. Putnam z kolei uważa, że kapitał społeczny skumulowany w społeczności lokalnej reprezentuje dobro publiczne, które również jest źródłem dla rozwoju dzieci. Jednak, jak sam przyznaje, nie do końca poznał mechanizm zależności między tym rodzajem kapitału a edukacyjnymi osiągnięciami. Stawia jednak hipotezę, wedle której wysoki kapitał społeczny wymusza, zarówno na rodzicach jak i na szerszej społeczności lokalnej, większe zaangażowanie w proces edukacji dzieci. W konsekwencji, zależność ta powoduje, że młodzi ludzie nabywają odpowiednich postaw zarówno w szkole, jak i poza nią ${ }^{15}$.

Niektóre opracowania zachodnie, jak i polskie wskazują na niski stopień zainteresowania uczestnictwem $\mathrm{w}$ życiu politycznym oraz społecznym (np. spadek aktywności w partiach politycznych, spadek aktywności w życiu Kościoła $)^{16}$, jednak pojawiają się organizacje, które przyciągają więcej zainteresowanych niż w minionych dekadach. Są to głównie ruchy na rzecz ekologii i ochrony środowiska naturalnego, ale także większym zainteresowaniem cieszą się organizacje promujące "indywidualne członkostwo", takie jak grupy wsparcia ${ }^{17}$. Niektórzy uważają (m.in. Putnam, Bauman, Beck, Giddens), że spadek aktywności obywatelskiej jest następstwem powstania społeczeństwa industrialnego oraz ponowoczesności, które w centrum stawiają jednostkę i jej potrzeby (indywidualizm), a nie kolektywną solidarność. Dlatego, z perspektywy tej ważne wydaje się budowanie kapitału społecznego i wzajemnego zaufania obywateli („aktywnego zaufania”, jak określił A. Giddens), zarówno w systemie szkolnym, jak i poza nim - w lokalnych społecznościach. Nie do końca należy zgodzić się z tezą, iż więzi społeczne oraz społeczne zaufanie spada we wszystkich społeczeństwach. Oto bowiem silny spadek zaangażowania społecznego i politycznego, a także większe przesunięcie w kierunku

15 Tamże, s. 80 .

16 Zob. H. Lopez, A. Kiesa, What we know about civic engagement among college students, [w:] Civic engagement in higher education. Concepts and practices, red. B. Jacoby and Associates, San Francisco 2009; C. McTighe Musil, Educating students for personal and social responsibility, [w:] Civic engagement in higher education. Concepts and practices, red. B. Jacoby and Associates, San Francisco 2009; Aktywność społeczna Polaków - poziom zaangażowania i motywacje - Raport z badań, Maj 2011, adres internetowy: http://erw2011.gov.pl/static/upload/komunikat-1.pdf, [dostęp: 20.04.2012]; A. Olech, Między zainteresowaniem a zaangażowaniem - aktywność obywatelska i organizacje pozarzadowe w Polsce, Analizy i Opinie, Numer specjalny, 2014, 7, s. 3.

17 D. Halpern, Social capital, s. 242. 
indywidualistycznej orientacji można zaobserwować zwłaszcza w krajach anglosaskich. Natomiast w Holandii, Japonii, czy Szwecji trendy te nie przedstawiają się aż tak pesymistycznie, przeciwnie - obserwuje się wzrost zaufania społecznego, wolontariatu, a także różnych form nieformalnej socjalizacji ${ }^{18}$.

Wokół koncepcji kapitału społecznego pojawiły się w ostatnich latach kontrowersje. Po pierwsze, stawiane jest pytanie: czy słusznie jest on nazywany „kapitałem"? W rozumieniu ekonomicznym kategoria ta może ulec zmniejszeniu, a nawet wyczerpaniu, natomiast kapitał społeczny ma zdolność pomnażania ${ }^{19}$. Po drugie, kontrowersyjne wydają się metody jego mierzenia, szczególnie te, w których wykorzystuje się pojęcie społecznego zaufania. Istnieją również rozbieżności w metodach pomiaru, wynikające z różnych uwarunkowań kulturowych ${ }^{20}$. Po trzecie, wielu badaczy krytycznie odnosi się do tej koncepcji, utrzymując, iż jest ona mglista i niedoskonała. Na przykład, Ben Fine twierdzi, iż kategoria ta jest „całkowicie chaotyczna, wieloznaczna i ogólna” i może być wykorzystana jako „hipotetyczny parasol dla niemalże każdego celu" ${ }^{\prime 2}$. Trzeba też zauważyć, że Putnam w swych rozważaniach dostrzega także "ciemną" stronę tej kategorii. Stara się bowiem dowieść, że na skutek zwiększenia kapitału społecznego, rośnie tolerancja w społeczeństwie, jednak może to odbywać się kosztem wspólnotowości. Podobnie rzecz traktuje z równością - im większa wspólnotowość, tym większa nierówność, która tworzy się w wyniku powstawania różnych enklaw społecznych, które wykluczają określone jednostki. Tradycyjne wspólnoty mogą ograniczać wolność jednostki oraz bywają opresyjne. Wyzwolenie się z oków więzi wspólnotowych prowadzi do zwiększenia tolerancji, przy jednoczesnym spadku ich siły. Potwierdzają to obserwacje przeprowadzone przez Putnama w społeczeństwie amerykańskim, które bez wątpienia było bardziej tolerancyjne w latach dziewięćdziesiątych niż pięćdziesiątych ${ }^{22}$. Amerykanie zaczęli funkcjonować wedle zasady „nie jesteśmy ze sobą już tak silnie związani, ale przynajmniej ja nie przeszkadzam tobie, a ty mnie"23. Z drugiej strony Putnam wskazuje, że osoby zaangażowane społecznie są bardziej otwarte i tolerancyjne niż izolujące się ${ }^{24}$. Do podobnych wniosków dochodzi David Halpern, stwierdzając, że

etniczna i społeczna heterogeniczność została uznana za czynnik spowalniający rozwój kapitału społecznego, obniżając stopień wzajemnego zaufania i chęci anga-

\footnotetext{
${ }_{18}$ Tamże, s. 216-222.

19 R.D. Putnam, Bowling alone, s. 58.

${ }^{20}$ D. Halpern, Social capital, s. 39.

${ }^{21}$ Tamże, s. 13.

22 R.D. Putnam, Bowling alone, s. 351-352.

${ }^{23}$ Tamże, s. 354.

${ }^{24}$ Tamże, s. 355.
} 
żowania się, nie tylko między poszczególnymi grupami społecznymi, lecz również wewnątrz nich ${ }^{25}$.

Z tej perspektywy, w odniesieniu do edukacji obywatelskiej i kształtowania kapitału społecznego w społecznościach lokalnych, istotne wydaje się mieszanie różnych grup społecznych w celu budowania pomostowego kapitału społecznego, jednak nie uda się to, jeśli wewnątrz danej grupy społecznej nie wytworzy się kapitał wiążący ${ }^{26}$. Istotne znaczenie $w$ tym zakresie przypisuje się systemowi szkolnemu.

\section{Zaufanie społeczne w Anglii i Polsce a aktywność obywatelska - zarys tendencji}

W niniejszym opracowaniu wykorzystano badania opinii publicznej dotyczące zaufania społecznego w Wielkiej Brytanii. Przekrojowe badania odnośnie tego problemu zostały przeprowadzane przez niezależną agencję badającą opinię publiczną NatCen. Wykorzystano Raport British Social Attitudes nr 35 z 2017 roku $^{27}$. Natomiast, polskie wyniki na temat społecznego zaufania zaczerpnięto z Centrum Badania Opinii Społecznej (CBOS) nr 18/201628. Wyróżnione kategorie diagnozujące poziom zaufania społecznego nie są komplementarne $\mathrm{w}$ przeprowadzonych sondażach, dlatego analizowane będą tendencje kształtowania zaufania społecznego w obydwu krajach.

Brytyjczycy wykazują wysoki poziom zaufania społecznego, 54\% respondentów uważa, że prawie zawsze lub zwykle można ufać innym ludziom. Odnotowano również wzrost poziomu zaufania w stosunku do ubiegłych lat, kiedy około 45\% Brytyjczyków deklarowało wysoki poziom zaufania wobec innych osób (zauważono również 7\% wzrost deklarowanego poziomu zaufania w stosunku do badania przeprowadzonego w 2014 roku ${ }^{29}$. W Polsce niespełna $23 \%$ ankietowanych uważa, że większości ludzi można ufać, podczas gdy $74 \%$ deklaruje ostrożność w stosunkach z innymi ludźmi. Zmalał jednak odsetek osób deklarujących nieufność (z 55\% do 47\%) w porównaniu z 2014 rokiem, ale także zaufanie (z 35\% do 32\%), powiększyła się natomiast liczba osób niemających w tej kwestii zdania (z 10\% do 21\% $)^{30}$. Z tej perspek-

${ }^{25}$ D. Halpern, Social capital, s. 281.

${ }^{26}$ Tamże.

${ }^{27}$ Zob. Y. Li, N. Smith, P. Dangerfield, Social trust. The impact of social networks and inequality, British Social Attitudes, 2017, 35.

${ }^{28}$ CBOS, Zaufanie społeczne, Komunikat z badań nr 18/2016, adres internetowy: https:/ / www.cbos.pl/SPISKOM.POL/2016/K_018_16.PDF, [dostęp: 1.12.2019]

29 Y. Li, N. Smith, P. Dangerfield, Social trust, s. 2-6.

${ }^{30}$ CBOS, Zaufanie spoteczne, s. 1. 
tywy Polacy cechują się nieufnością we wszystkich grupach społeczno-demograficznych. W przypadku Brytyjczyków najniższy odsetek deklarowanego zaufania do ludzi występuje $w$ grupie o niskich kwalifikacjach zawodowych i podstawowym wykształceniu, ale i tak wynosi on $42 \%$. W przypadku osób z wyższym wykształceniem odsetek ten wynosi $64 \%$, a dla osób ze średnim wykształceniem $50 \%{ }^{31}$. Natomiast w przypadku polskich respondentów indeks zaufania przyjmuje wartość dodatnią jedynie dla absolwentów uczelni wyższych (wartość wskaźnika 0,12). Wyższe wskaźniki zaufania społecznego zarówno dla Brytyjczyków i Polaków korelują z wykształceniem, stanowiskiem pracy, dochodami oraz miejscem zamieszkania (mieszkańcy większych miast deklarują wyższy poziom zaufania). Wyższy stopień zaufania społecznego w obydwu krajach deklarują osoby starsze ${ }^{32}$. W Polsce osoby w grupach wiekowych 18-34 lata cechują się niższym poziomem zaufania wobec innych osób ${ }^{33}$. Jednakże, w przypadku Brytyjczyków poziom zaufania jest wysoki, podczas gdy w Polsce przeważa nieufność nad ufnością i otwartą postawą we wszystkich grupach społecznych. Niepokojącym zjawiskiem, według Diagnozy Społecznej 2015, jest spadek i tak już niskiego zaufania społecznego Polaków oraz aktywności społecznej, mimo poprawiających się wskaźników dotyczących jakości życia i poczucia szczęścia ${ }^{34}$.

Z powyższych opracowań wynika, że osoby z wyższym wykształceniem oraz zajmujące wyższe miejsce $\mathrm{w}$ hierarchii społecznej manifestują wyższy stopień zaufania społecznego (w przypadku Brytyjczyków tendencja ta jest wyraźniejsza). Według autorów brytyjskiego Raportu (ale również według Putnama czy Halperna), osoby legitymujące się wyższym wykształceniem oraz o stabilnej sytuacji finansowej z tytułu swojej pozycji społecznej mogą wykazywać bardziej optymistyczne spojrzenie na świat, odczuwać większe poczucie kontroli i sprawstwa nad własnym życiem, a przeto być bardziej ufnym wobec innych ludzi ${ }^{35}$. Jednakże, według przywołanych badaczy, wysoki poziom zaufania społecznego może być efektem, a nie przyczyną podejmowania częstszej aktywności społecznej i obywatelskiej. Brytyjskie badania potwierdzają również tezę o pozytywnej korelacji między stopniem zaufania społecznego a aktywnością społeczną i obywatelską. Osoby cechujące się zaufaniem wobec ludzi częściej podejmują działania na rzecz innych, zrzeszając

${ }^{31}$ Y. Li, N. Smith, P. Dangerfield, Social trust, s. 2-6.

${ }^{32}$ Tamże; CBOS, Zaufanie społeczne, s. 5.

${ }^{33}$ CBOS, Zaufanie spoteczne, s. 5.

${ }_{34}$ Zob. J. Czapiński, T. Panek, Diagnoza społeczna 2015. Warunki i jakość życia Polaków, Warszawa 2015; zob. również: A. Wiłkomirska, Wiedzieć i rozumieć, aby być obywatelem. Studium empiryczne, Warszawa 2013, s. 49-56.

${ }^{35}$ Y. Li, N. Smith, P. Dangerfield, Social trust, s. 8; por. także D. Halpern, Social capital; R.D. Putnam, Bowling alone. 
się $\mathrm{w}$ organizacjach pozarządowych, partiach politycznych, czy podejmując pracę $\mathrm{w}$ ramach wolontariatu.

Odsetek osób cechujących się wysokim stopniem zaufania wobec innych osób, które podejmowały aktywność o charakterze społecznym (w grupach rekreacyjnych, sportowych lub kulturalnych) kilkakrotnie w ciągu roku wyniósł $62 \%$, przynajmniej raz $51 \%$, a nigdy $44 \%$. Natomiast odsetek osób podejmujących aktywność o charakterze obywatelskim (wolontariat, działania $\mathrm{w}$ organizacjach charytatywnych i religijnych) kilkakrotnie $\mathrm{w}$ ciągu roku oraz przynajmniej raz $\mathrm{w}$ roku wynosił $62 \%$, natomiast nigdy takiej aktywności $\mathrm{w}$ grupie osób o wysokim stopniu zaufania społecznego nie podjęło $44 \%$ badanych. Autorzy Raportu wskazują, że im częściej osoba podejmuje aktywność o charakterze społecznym czy obywatelskim, tym wykazuje się większym stopniem zaufania wobec innych osób ${ }^{36}$.

Przywołane wcześniej badanie CBOS-u nie dostarcza informacji dotyczących relacji między stopniem zaufania społecznego a podejmowaniem aktywności społecznej i obywatelskiej. O aktywności obywatelskiej i społecznej Polaków możemy dowiedzieć się z innych dokumentów. Badania CBOS-u z 2016 roku wskazują, że Polacy nadal charakteryzują się niską potrzebą afiliacji i partycypacji społecznej. 63\% respondentów nie działa w żadnej organizacji o charakterze obywatelskim, aczkolwiek w porównaniu $\mathrm{z}$ badaniem z 2012 roku liczba osób deklarujących aktywność w organizacji wzrosła o pięć punktów procentowych. Najwięcej osób deklarujących przynależność i aktywność $\mathrm{w}$ organizacjach obywatelskich ma wyższe wykształcenie, pracuje jako kadra kierownicza lub specjaliści wyższego szczebla (68\%), drugą grupą są uczniowie i studenci $(56 \%)^{37}$. Najwięcej osób angażuje się w przedziale wiekowym między 35. a 44. rokiem życia oraz ci, którzy demonstrują wyższy wskaźnik częstotliwości praktyk religijnych ${ }^{38}$. Przywołane badania CBOS-u z 2016 roku wskazują, że Polacy najczęściej podpisują petycję (18\%), a 14\% kwestuje (zbierało lub przekazało pieniądze na ważny cel).

Dla porównania z respondentami w Anglii, posłużę się danymi pochodzącymi z dokumentu Citizenship Survey 2008-0939. 47\% respondentów przy-

${ }^{36}$ Y. Li, N. Smith, P. Dangerfield, Social trust, s. 1 i 9.

${ }_{37}$ CBOS, Aktywność Polaków w organizacjach obywatelskich, Komunikat z badań nr 13/2016, Centrum Badania Opinii Społecznej CBOS, Warszawa 2016, s. 4-8; zob. również X. Bukowska, E. Wnuk-Lipiński, Obywatelskość a la polonaise - czyli jakimi obywatelami są Polacy? Nauka, 2009, 1.

${ }^{38}$ CBOS, Aktywność Polaków w organizacjach obywatelskich, s. 4-8; Z. Kinowska, Kondycja spoteczeństwa obywatelskiego w Polsce, INFOS, Biuro Analiz Sejmowych, nr 22, 2012.

${ }^{39}$ Citizenship Survey 2008-09 dostarcza informacji o poczuciu sprawstwa w życiu publicznym Anglii i Wielkiej Brytanii. NatCen nie przeprowadzało od tamtego czasu tego typu sondażu na terenie Wielkiej Brytanii, adres internetowy: https:// webarchive.nationalarchives.gov. uk/20120919213933/http://www.communities.gov.uk/documents/statistics/pdf/1284311. pdf [dostęp: 1.12.2019]. 
znało, że przynajmniej raz w ciągu ostatniego roku podjęło aktywność o charakterze obywatelskim. Najczęstszą formą działania obywatelskiego było - podobnie jak w przypadku Polski - podpisywanie petycji (60\%), aczkolwiek odsetek Anglików jest znacznie wyższy niż Polaków. Anglicy również często biorą udział w konsultacjach społecznych (21\%), z czego najbardziej powszechną formą było wypełnienie ankiety dotyczącej lokalnych problemów (67\%). Jeśli chodzi o bezpośrednią formę zaangażowania obywatelskiego, to takie działania deklaruje 10\% (np. bycie radnym, członkiem rady szkoły itp.). W tym przypadku najbardziej popularną formą działania jest pełnienie funkcji członka rady szkoły $11 \%$.

$\mathrm{W}$ angielskich raportach nie istnieje podział na zbieranie i dawanie pieniędzy, jednak przekazanie środków finansowych stanowi osobną, istotną kategorię w badaniach aktywności obywatelskiej. Dane pochodzące z przywołanego wyżej Raportu wskazują, że $74 \%$ Anglików przekazało pieniądze na działalność charytatywną w latach 2008-2009. 26\% Anglików deklaruje podjęcie formalnej pracy $\mathrm{w}$ ramach wolontariatu przynajmniej raz $\mathrm{w}$ miesią$\mathrm{cu}$, natomiast $35 \%$ - nieformalnej.

Polskie badania dostarczają dane dotyczące podejmowania aktywności wolontaryjnej $\mathrm{w}$ perspektywie roku poprzedzającego sondaż. Badania CBOS-u z 2018 roku wskazują, że 23\% respondentów zadeklarowało, iż $\mathrm{w}$ tym przedziale czasowym podjęło się pracy w charakterze wolontariusza. Natomiast badanie CBOS-u z 2011 roku wskazuje, że aż 48\% osób $\mathrm{w}$ ciągu ostatniego roku przynajmniej raz zaangażowało się w dobrowolną i nieodpłatną pracę na rzecz osób nieznajomych, lokalnej wspólnoty lub na rzecz jakiejś organizacji społecznej. Jednocześnie w tak zwany „,wolontariat pośredni” (formalny), a zatem wykonywany poprzez organizacje angażowało się 28\%. Należy także podkreślić, iż badanie z 2011 wskazuje, że wielu respondentów nie rozumie, co znaczy praca wolontariusza i myli pojęcie wolontariatu z innymi działaniami podejmowanymi w celach społecznych (np. 26\% respondentów uważa, że wysłanie dobroczynnego SMS-a wpisuje się w ramy wolontariatu).

Przywołane badanie potwierdza również wyniki poprzednich, wskazujących na silną relację między podejmowaniem aktywności społeczno-politycznej a kapitałem społecznym (wykształcenie, zamieszkanie, dochód) oraz niższym wiekiem respondentów. Xymena Bukowska wraz z Edwardem Wnukiem-Lipińskim w następujący sposób wyjaśniają tę zależność:

im wyższe wykształcenie, tym - statystycznie rzecz biorąc - silniejsze przesunięcie od postaw autorytarnych $\mathrm{w}$ kierunku prodemokratycznych, tym więcej poczucia podmiotowości, a mniej odruchów stadnych, tym bardziej złożone tożsamości społeczne, tym wyraźniej obywatelstwo definiowane jest w kategoriach inkluzywnych i wreszcie 
- tym wyraźniejsze przesunięcie od narodowego partykularyzmu w kierunku europejskiego uniwersalizmu ${ }^{40}$.

Od początku okresu transformacyjnego do około 2007-2008 roku niewielki odsetek Polaków czuł, że ma wpływ na wydarzenia społeczno-polityczne $\mathrm{w}$ Polsce. Jednak stopniowo odzyskują poczucie sprawstwa i zaczynają dostrzegać swoje możliwości obywatelskie. Podmiotowość obywatelska jest widoczna szczególnie $\mathrm{w}$ odniesieniu do działań w środowisku lokalnym. W 2015 roku 49\% respondentów uważało, że ma poczucie wpływu na to, co dzieje się w ich mieście lub gminie, a rok później - już 56\%. Poczucie sprawstwa w życiu publicznym w wymiarze krajowym deklarowało $41 \%$ respondentów, co daje najwyższy wskaźnik od 1992 roku $^{41}$.

Jeśli porównamy dane statystyczne z dokumentu Citizenship Survey 2008$09^{42}$, to zauważymy, że 39\% osób uważa, że ma wpływ na sprawy lokalne w Anglii, natomiast na sprawy Zjednoczonego Królestwa - jedynie 20\%. Jest to ciekawe zestawienie, pokazujące, że w sferze deklaratywnej Polacy odczuwają znacznie większe poczucie sprawstwa na kwestie lokalne i krajowe niż Brytyjczycy. W sferze partycypacji obywatelskiej widać rozbieżność, bowiem to Anglicy częściej podejmują działania o charakterze lokalnym niż Polacy. W latach 2008-2009 38\% respondentów przyznało, że angażowało się w jakąś formę działalności obywatelskiej.

Istotnym wskaźnikiem aktywności obywatelskiej jest czynny udział w wyborach. W wyborach do Sejmu w 2019 roku frekwencja wyniosła 61,74\% i była najwyższa w historii wyborów parlamentarnych ${ }^{43}$. Przy czym, ostatnie dwie dekady wskazują na tendencję wzrostową frekwencji $w$ tego rodzaju wyborach. Ostatni wynik frekwencji wyborczej zbliża nas do średniej krajów Europy Zachodniej. W wyborach parlamentarnych w 2019 roku w Wielkiej Brytanii frekwencja wynosiła $67,3 \%$. W porównaniu z poprzednimi latami utrzymuje się na podobnym poziomie, jest wyższa niż w wyborach w 2001 i 2005 roku, jednak niższa aniżeli w 1992 (77\%) czy 1979 roku $(76 \%)^{44}$.

Wydaje się, że wzrost frekwencji wyborczej wśród polskich obywateli może budzić optymizm. Optymistyczne też wydają się tendencje podejmowanych działań na rzecz wolontariatu czy innych aktywności społecznych.

40 X. Bukowska, E. Wnuk-Lipiński, Obywatelskość a la polonaise, s. 45.

${ }^{41}$ CBOS, Aktywność społeczno-polityczna Polaków, s. 2.

42 Citizenship Survey 2008-09, adres internetowy: https:// webarchive.nationalarchives.gov. uk/20120919213933/http://www.communities.gov.uk/documents/statistics/pdf/1284311. pdf [dostęp: 1.12.2019].

43 Krajowe Biuro Wyborcze, Wybory do Sejmu i Senatu Rzeczpospolitej Polskie 2019, adres internetowy: www.wybory.gov.pl [dostęp: 2.12.2019].

44 House of Commons, General Election 2019: full results and analysis, adres internetowy: https:/ / researchbriefings.parliament.uk/ResearchBriefing/Summary/CBP-8749, [dostęp: 2.01.2020]. 
Niemniej jednak, mimo tendencji wzrostowej nadal niski pozostaje stopień zaufania społecznego, który jest raczej efektem, a nie przyczyną podejmowania aktywności obywatelskiej. $Z$ tej perspektywy wzrost zaufania społecznego będzie pozytywnie wpływał na budowanie społeczeństwa obywatelskiego w Polsce. Przywołane dotychczas opracowania wskazują na silną korelację między wykształceniem, wykonywanym zawodem, pozycją społeczną a poziomem zaufania. Wydaje się zatem, iż jedną $\mathrm{z}$ istotnych ról $\mathrm{w}$ budowaniu zaufania społecznego odgrywa edukacja i system szkolnictwa.

\section{Edukacja obywatelska a budowanie kapitału społecznego i zaufania społecznego}

W świetle powyższych analiz potwierdza się teza, postawiona między innymi przez Putnama czy Colemana, o pozytywnej korelacji między wykształceniem a kapitałem społecznym oraz zaufaniem społecznym. Trzeba jednak zauważyć, że budowanie zaufania społecznego w systemie szkolnym jest procesem złożonym, wykraczającym zapewne poza zapisy w strategicznych dokumentach oświatowych i podstawach programowych. Budowanie szkoły demokratycznej, otwartej, wychowującej w duchu zaufania społecznego i przygotowującej młodych ludzi do życia w społeczeństwie obywatelskim wymaga postawienia kluczowych pytań: jakich obywateli potrzebujemy? Jakie cnoty powinny być krzewione? Jak powinna wyglądać współpraca między szkołą, rodzicami a środowiskiem lokalnym? Jaką rolę odgrywa szkoła w socjalizacji i wychowaniu przyszłych obywateli?

Dyskurs obywatelstwa nie był akcentowany w angielskiej szkole. Zmiany nastąpiły wraz z dojściem do władzy Partii Pracy w 1997 roku. Wydany rok później tak zwany Raport Cricka stanowił podstawę dla wprowadzenia obowiązkowej ścieżki edukacji obywatelskiej (jako osobnego przedmiotu) do szkół średnich. W 2002 roku do angielskich szkól wprowadzono obowiązkowy przedmiot "Citizenship". U podstaw jego implementacji było dążenie do budowania jedności społecznej (social cohesion), kształtowania wspólnej tożsamości narodowej (Britishness) oraz promocja aktywnego obywatelstwa w celu przezwyciężenia tak zwanej politycznej apatii i deficytu demokratycznego wśród młodych ludzi ${ }^{45}$. Nauczycielom pozostawiono autonomię w zakresie podejmowania decyzji odnośnie realizacji programu nauczania tak, by wpisywał się on w oczekiwania środowiska lokalnego, a tym samym ograniczono

${ }^{45}$ Zob. D. Hejwosz-Gromkowska, Edukacja obywatelska we wspótczesnej Anglii. Studium socjopedagogiczne, Poznan 2019; D. Kerr, A. Smith. C. Twine, Citizenship education in the United Kingdom, [w:] Education for citizenship and democracy, red. J. Arthur, I. Davies, C. Hahn, London 2008, s. 252-255. 
możliwość kontrolowania ze strony rządu delikatnych kwestii związanych z obywatelstwem ${ }^{46}$. W toku ewolucji strategii edukacji obywatelskiej w angielskich szkołach wprowadzono również do programów nauczania aspekty dotyczące różnorodności (etnicznej, kulturowej, ekonomicznej itp.) oraz tożsamości ${ }^{47}$. Duże znaczenie w polityce oświatowej w kontekście edukacji obywatelskiej przypisuje się również środowisku lokalnemu. Z tak obranego założenia szkoła staje się sercem społeczności lokalnej, w której buduje się promowaną jedność społeczną. Dokumenty strategiczne kładą na szkołach odpowiedzialność za budowanie jedności społecznej (czyli wspólnotowości i odpowiedzialności, których niezbędnym elementem jest zaufanie społeczne), jednak działania podejmowane przez społeczność szkolną mają uwzględniać profil etniczny i wyznaniowy społeczności lokalnej ${ }^{48}$. W tym kontekście Alveena Malik analizując rolę szkół w edukacji obywatelskiej zauważa:

w każdej społeczności lokalnej jej sercem może stać się szkoła (i faktycznie na wielu obszarach tak się stało), będąc bezpiecznym miejscem dla dzieci, rodzin oraz innych osób, tak by mogli wchodzić ze sobą w interakcję, pozbywać się uprzedzeń, a także by uczyć, nie tylko dzieci, wzajemnego zaufania, tak by mogli stać się dobrymi sąsiadami i aktywnymi obywatelami ${ }^{49}$.

Przywołana autorka wskazuje, że największy sukces w osiąganiu kohezji społecznej odnoszą szkoły aktywnie współpracujące z władzami samorządowymi oraz innymi kluczowymi partnerami na szczeblu lokalnym. W celu zwiększenia zarówno jedności społecznej, jak też aktywności obywatelskiej i społecznej, wprowadzane są różnego rodzaju inicjatywy, w ramach których uczniowie podejmują decyzje odnośnie funkcjonowania ich środowiska lokalnego. Dzięki temu uczą się, że mają realny wpływ na kształt wspólnoty, a poprzez aktywną partycypację dowiadują się, że ważne decyzje nie są jedynie podejmowane odgórnie ${ }^{50}$.

Istotnym aspektem implementacji i realizacji celów edukacji obywatelskiej w Anglii było wprowadzenie monitoringu podjętych działań. Ich efektem były badania o charakterze longitudinalnym, których wyniki zostały przedstawio-

${ }^{46}$ Zob. A. Petersen, Where now for citizenship education? [w:] Debates in citizenship education, red. J. Arthur, H. Cremin, London - New York 2012, s. 196; J. Beck, A brief history of citizenship education in England and Wales, [w:] Debates in citizenship education, red. J. Arthur, H. Cremin, London - New York 2012, s. 8.

47 J. Beck, A brief history of citizenship education, s. 8-10; P. Brett, Identity and Diversity: Citizenship Education and Looking Forwards from the Ajegbo Report, 2007, http:/ / www.citized.info/pdf/ commarticles/Peter\%20Brett\%20\%20Identity\%20and\%20Diversity.pdf [dostęp: 21.03.2017].

48 A. Malik, Citizenship education, race and community cohesion, [w:] Debates in citizenship education, red. J. Arthur, H. Cremin, London - New York 2012, s. 69-70.

49 Tamże, s. 70.

50 Tamże, s. 74. 
ne w raportach Citizenship Education Longtidual Study 2001-2009 (CELS 2010). Badanie to przeprowadza się od 2001 roku i ma ono charakter zewnętrznej, podłużnej (dynamicznej) ewaluacji zarówno procesu implementowania do szkół edukacji obywatelskiej, jak i jej znaczenia. Do tej pory stanowi ono największe i najdłużej trwające badanie efektów edukacji obywatelskiej na świecie. Dane zbierane są za pomocą metod jakościowych i ilościowych (m.in. analiza dokumentów, analiza literatury oraz wywiady z nauczycielami, uczniami i kadrą zarządzającą). W latach 2002-2003 grupą objętą badaniami były dzieci w wieku 11-12 lat wchodzące w siódmy rok nauki; następne przeprowadzono w 2005 roku, czyli w dziewiątym roku nauki (13-14 lat), a kolejne odbyły się w jedenastym roku nauki (15-16 lat) i w trzynastym (17-18 lat). Ostatnie badania w tej grupie przeprowadzono pod koniec 2014 roku wśród osób w wieku 22-29 lat, a jego wyniki zostały opublikowane w pracach Avril Keating i współpracowników. Z kolei, Raport Citizens in Transition - Civic Engagement and Political Participation among Young People 2001-201151 stanowi odrębną część CELS, obejmując młodzież w wieku 19-20 lat, która ukończyła szkołę średnią. Celem badań było sprawdzenie efektywności szkolnej edukacji obywatelskiej we wczesnej dorosłości. Część ich uczestników była uprzednio objęta badaniem CELS.

Przywołane Raporty ukazują pozytywną korelację między prowadzeniem edukacji obywatelskiej w szkołach a aktywnością obywatelską młodych Anglików. Między 2001 a 2009 rokiem (według Citizenship Education Longtidual Study 2001-2009 - CELS) odnotowano stały i znaczący wzrost liczby osób zaangażowanych w działalność polityczną, taką jak podpisywanie petycji oraz wybory do samorządów szkolnych. Niewielka jednak liczba uczniów brała udział w innych formach aktywności politycznej. Nastąpił również wzrost partycypacji społecznej i obywatelskiej, a najczęściej wskazywanym działaniem stała się zbiórka pieniędzy na istotne cele społeczne, choć wraz z wiekiem odnotowuje się rosnącą liczbę osób pomagających w społeczności lokalnej ${ }^{52}$. Badanie CELS z 2014 roku pokazuje, że młodzież u progu swojej dorosłości (między 16. a 18. rokiem życia) deklaruje potrzebę i chęć aktywności społecznej, obywatelskiej i politycznej. Rekomenduje się zatem większy nacisk na edukację obywatelską (wprowadzenie jej jako osobnego przedmiotu) dla młodzieży kontynuującej naukę na poziome sixth form ${ }^{53}$. Zaobserwowano również przeniesienie aktyw-

${ }^{51}$ Zob. L. Sturman i in., Citizens in Transition - Civic Engagement and Political Participation among Young People 2001-2011, Economic and Social Research Council (ESRC), National Foundation for Educational Research (NFER), 2012.

${ }^{52}$ A. Keating i in., Citizenship education in England 2001-2010: young people's practices and prospects for the future: the eighth and final report from the Citizenship Education Longitudinal Study (CELS), Department for Education 2011, s. v.

53 A. Keating, A. Green, G. Janmaat, Young Adults and Politics Today: disengaged and disaffected or engaged and enraged?: The latest findings from the Citizenship Education Longitudinal Study (CELS), Working Paper 2015, adres strony: http://eprints.ioe.ac.uk/21838/, [dostęp: 11.11.2017], s. 1. 
ności społecznej do wirtualnej rzeczywistości. Przywołane badania CELS wskazują więc, że 41\% użytkowników Facebooka dołączyło do grupy o charakterze polityczno-społecznym, choć jedynie 3,6\% zadeklarowało, iż założyło taką grupę $e^{54}$. Do aktywności obywatelskiej online młodych Brytyjczyków należy jednak podejść z dystansem, gdyż obszar ten jest dopiero eksplorowany.

Głównym motywem podejmowanych działań społecznych i politycznych przez młodych ludzi są osobiste korzyści, a nie potrzeba wypełniania obowiązku ${ }^{55}$ - obywatelskiego czy patriotycznego. Podejście to wpisuje się w indywidualistyczną orientację, działanie we własnym interesie, a nie w imię wyższego dobra (np. ojczyzny), sprawiedliwości społecznej, przyszłych pokoleń i tym podobnych. Innymi słowy, młodzi ludzie są bardziej zorientowani na "tu i teraz", są realistami, a nie marzycielami walczącymi w imię idei, choć należy zauważyć, że wraz z wiekiem następuje przesunięcie z orientacji liberalnej w kierunku konserwatywnej, szczególnie w kwestiach imigrantów, uchodźców, wyroków sądowych, emerytur i problemów środowiska naturalnego ${ }^{56}$.

Należy jednak zaznaczyć, że ewaluacja edukacji obywatelskiej w Anglii nie daje pozytywnych wyników w zakresie budowania jedności społecznej w szkole. Z tej perspektywy autorzy Raportu badań CELS wskazują na konieczność zwiększenia liczby działań edukacyjnych na poziomie szkolnym zarówno w wymiarze formalnym - poprzez uwzględnienie edukacji obywatelskiej w programach nauczania - jak i nieformalnym - poprzez działania w środowisku lokalnym, aktywizowanie rad szkolnych oraz innych działań na rzecz aktywnego obywatelstwa. Autorzy badań konkludują, że edukacja obywatelska przynosi pozytywne efekty w zakresie zwiększenia aktywności obywatelskiej, jeśli jest ona odpowiednio prowadzona w szkole. Ponadto, podnoszą oni argument zwiększenia liczby godzin przeznaczonych na ten obszar zagadnień, gdyż uzyskane wyniki badań wskazują na silną korelację między aktywnością obywatelską a czasem przeznaczonym w szkole na edukację obywatelską ${ }^{57}$. Innymi słowy, szkoły, które prowadzą zarówno formalną edukację obywatelską, jak i dają możliwość uczniom aktywnego uczestnictwa w życiu szkoły poprzez codzienne doświadczenia, wyrabiają w uczniach pozytywne postawy wobec działalności społecznej, politycznej i publicznej, a to z kolei wpływa na ich gotowość do podejmowania aktywnych działań na rzecz społeczności lokalnej.

${ }^{54}$ A. Keating, D. Kerr, Putting participation into practice: re-evaluating the implementation of the Citizenship curriculum in England, [w:] Education for Civic and Political Participation: A Critical Approach, red. R. Hedtke, T. Zimenkova, London 2013, s. 121.

55 A. Keating i in., Citizenship education in England 2001-2010, s. v.

56 Tamże, s. vi.

${ }^{57}$ A. Keating, A. Green, G. Janmaat, Young Adults and Politics Today, s. 7. 
Edukacja obywatelska w polskiej szkole ma charakter rozproszony. Zagadnienia $\mathrm{z}$ tego zakresu realizowane są $\mathrm{w}$ ramach różnych przedmiotów, głównie języka polskiego, historii i geografii. Przedmiotem, który realizuje cele edukacji obywatelskiej explicite jest wiedza o społeczeństwie. W odróżnieniu od przywołanego w niniejszym artykule przykładu Anglii, mimo reform podstawy programowej $(2002,2008$ oraz 2017) nie wprowadzono systemowych rozwiązań mających na celu rozwój edukacji obywatelskiej w szkole. Działania legislacyjne, wprowadzające zmiany $\mathrm{w}$ podstawach programowych, dotyczą głównie nauczanych treści, natomiast brakuje długofalowej strategii, określenia, jakich obywateli należy kształcić w systemie szkolnym, opracowania celów wychowawczych i kształcenia przyszłych obywateli oraz wprowadzenia monitoringu w zakresie ich realizacji. Według analizy przeprowadzonej przez Violettę Kopińską, w podstawie programowej z 2008 roku dla III i IV etapu edukacyjnego dominują wymagania odnoszące się do wiedzy $(86,5 \%)$, następnie do umiejętności $(27,8 \%)$ oraz postaw $(13,5 \%)^{58}$. Natomiast, $\mathrm{w}$ podstawie programowej z 2017 roku dla zreformowanej szkoły podstawowej 93\% wymagań ogólnych odnosiło się do wiedzy ${ }^{59}$. Z tej perspektywy edukacja obywatelska realizowana w ramach szkolnego przedmiotu wiedzy o społeczeństwie stanowi raczej nauczanie "o" niż nauczanie "dla” demokracji i społeczeństwa obywatelskiego. Przywołana autorka zauważa również, że najwięcej wymagań w dziedzinie wiedzy dotyczy systemu politycznego i prawnego na poziomie krajowym oraz na europejskim. Ponadto, marginalnie traktowane są tematy różnorodności kulturowej i religijnej w Europie i na świecie ${ }^{60}$. Należałoby również dodać, iż bardzo ograniczone są wątki dotyczące różnorodności etnicznej, narodowej na poziomie krajowym, brakuje też odniesień (podobnie jak w Anglii) do tematyki ekologicznej i zrównoważonego rozwoju. V. Kopińska wskazuje, że w obszarze umiejętności relatywnie dużo treści dotyczy kształtowania własnego zdania, a także krytycznej oceny przekazu medialnego. Natomiast, mniej uwagi poświęcone zostało kształtowaniu umiejętności w zakresie uczestnictwa w demokratycznych procesach (poza wyborami), zajęcia stanowiska i jego obrony (sztuka argumentacji),

${ }^{58}$ V. Kopińska, Edukacja obywatelska. Krytyczna analiza dyskursu podręczników szkolnych, Toruń 2017, s. 103; por. również H. Solarczyk-Szwec, V. Kopińska, A. Matusiak, Kompetencje społeczne na wejściu w dorostość. Krytyczna analiza podstawy programowej kształcenia ogólnego dla IV etapu edukacyjnego, Edukacja Dorosłych, 2016, 2.

${ }_{59}$ Rozporządzenie Ministra Edukacji Narodowej z 14 lutego 2017 r. w sprawie podstawy programowej wychowania przedszkolnego oraz podstawy programowej kształcenia ogólnego dla szkoły podstawowej, w tym dla uczniów z niepełnosprawnością intelektualną w stopniu umiarkowanym lub znacznym, kształcenia ogólnego dla branżowej szkoły I stopnia, kształcenia ogólnego dla szkoły specjalnej przysposabiającej do pracy oraz kształcenia ogólnego dla szkoły policealnej.

${ }^{60}$ V. Kopińska, Edukacja obywatelska, s. 103. 
rozumienia innych poglądów, krytycznej oceny rozwiązań i praktyk w sferze politycznej. Z kolei, w sferze postaw brakuje kształtowania gotowości do politycznego zaangażowania się, wspieranie różnorodności i spójności społecznej ${ }^{61}$. Trzeba zwrócić uwagę, że kształtowanie postaw obywatelskich nie ogranicza się jedynie do przedmiotu wiedza o społeczeństwie. Statuty szkolne, jako istotne dokumenty sankcjonujące pozycje uczniów w szkole, prezentują jej etos w zakresie wychowania (nie)demokratycznego, a nie tylko edukacji o demokracji. Chodzi tu głównie o wspólne podejmowanie decyzji odnośnie funkcjonowania szkoły i włączanie uczniów w codzienne życie szkoły. Badania Bożeny Kubiczek jednoznacznie wskazują, że uczniowie są wykluczani w procesie podejmowania decyzji w szkołach; opinia ta została wyrażona przez większość nauczycieli biorących udział w badaniu, twierdzących, że normy te określane są przez zespół nauczycieli w danej szkole ${ }^{62}$.

Nic więc dziwnego, że wielu pedagogów oraz socjologów zauważa, że polska szkoła nie rozwija kompetencji obywatelskich, a jej klimat nie służy budowaniu kapitału społecznego i zaufania społecznego. Bogusław Śliwerski opisuje polską oświatę jako inhibitor zmian społecznych, szczególnie w zakresie demokratyzacji, powiększania kapitału społecznego oraz budowania zaufania wśród członków społeczeństwa ${ }^{63}$. Maria Dudzikowa zauważa, że $\mathrm{w}$ polskiej rzeczywistości deficyt zaufania zaspokajany jest przez tak zwane jego "funkcjonalne substytuty”, którymi są między innymi paternalizm, wprowadzenie ochrony czy monitoringu ${ }^{64}$. Zdaniem przywołanej pedagoż$\mathrm{ki}$, zamiast demokratyzacji szkoły mamy do czynienia raczej z tresurą, dehumanizacją i uprzedmiotowieniem jednostki ludzkiej oraz jej relacji ze światem. W żaden sposób nie sprzyja budowaniu kapitału społecznego, zaufania społecznego i zdrowych więzi społecznych ${ }^{65}$.

Nabywanie wiedzy o demokracji, obywatelstwie, społeczeństwie obywatelskim, partycypacji społecznej i samorządności przejawia się w codziennym teatrze życia szkolnego. Problem ten podnosi między innymi Bogusław Śliwerski wskazując na deficyt uspołecznienia polskich szkół. Wyniki jego badań wskazują na bardzo niską liczbę powoływanych rad szkół, niewystarczającą współpracę między tym organem a rodzicami. Uczony ten zauważa, że w kontekście powoływania rad szkół głos członków samorządu uczniowskiego wydaje się, że nie jest brany pod uwagę. Warto też zauważyć, że na

${ }^{61}$ Tamże, s. 104.

${ }^{62}$ B. Kubiczek, Projekt „Szkoła Demokracji - Szkoła Samorząności”. Kompetencje społeczne i obywatelskie uczniów i nauczycieli. Materiaty dla uczestnika Konferencji, Sosnowiec 2012, s. 21.

${ }_{63}$ Zob. B. Śliwerski, Diagnoza uspołecznienia publicznego szkolnictwa III RP. W Gorsecie centralizmu, Kraków 2013.

${ }^{64}$ M. Dudzikowa, Erozja kapitatu społecznego w szkole w atmosferze nieufności, [w:] Kapitał społeczny w szkołach różnego szczebla. Diagnoza i uwarunkowania, Kraków 2011, s. 41.

${ }^{65}$ Tamże, s. 47. 
poziomie centralnym - a zatem w ośrodkach władzy - istnieje niski stopień zainteresowania problematyką uspołecznienia szkół, w tym funkcjonowania rad szkolnych ${ }^{66}$. Samorząd uczniowski - mimo że jest organem statutowym w szkole - w wielu aspektach działa "na papierze". Potwierdzają to badania przeprowadzone między innymi przez Violettę Kopińską ${ }^{67}$ czy Renatę Szczepanik $^{68}$. Świadczą o tym również wyniki porównawcze międzynarodowych badań International Civic and Citizenship Study 200969, które wskazują, że chociaż polscy uczniowie często biorą udział w wyborach do samorządu klasowego czy uczniowskiego, to w porównaniu z ich rówieśnikami z innych krajów deklarują, że mają małe poczucie wpływu na decyzje podejmowane przez inne organy szkoły, dotyczące takich kwestii, jak rozkład zajęć, statuty, regulaminy i tym podobne. Być może, niskie poczucie sprawstwa już na etapie edukacji szkolnej objawia się potem nadal niską frekwencją wyborczą osób dorosłych, bowiem wszelkie głosowania, w których brali udział jako młodzi ludzie, nie miały wiele wspólnego z demokratycznym podejmowaniem decyzji i współodpowiedzialnością.

Niepokojące wyniki badań uzyskała Bożena Kubiczek w zakresie demokratyzacji szkół ponadgimnazjalnych. Pokazują one, że

10,2\% uczniów zasadniczych szkół zawodowych, 8,30\% - techników i 5,42\% - liceów ogólnokształcących stwierdziło, iż nauczyciel (najpewniej wychowawca) wybierał szkolnych i klasowych przedstawicieli samorządu uczniowskiego ${ }^{70}$.

Obserwowana tendencja- zwłaszcza w ZSZ - wskazuje na autokratyczny klimat szkoły, który $\mathrm{w}$ zestawieniu $\mathrm{z}$ okrojoną podstawą programową z edukacji obywatelskiej sygnalizuje, że absolwenci tego typu szkół są nieodpowiednio przygotowywani do właściwego wypełniania roli obywatela. Badania Kubiczek potwierdzają tezę o pozorności działań obywatelskich i demokratycznych $\mathrm{w}$ przestrzeni szkolnej, bowiem niecałe $50 \%$ respondentów doświadczyło demokratycznego wyboru przedstawicieli szkolnych ${ }^{71}$.

W szkołach organizowane są między innymi przez Centrum Edukacji Obywatelskiej (CEO) i Fundację Batorego tak zwane prawybory (do samorządu i parlamentu). Ich celem jest przygotowanie młodych ludzi do czynnej partycypacji w wyborach $\mathrm{w}$ dorosłym życiu. Mimo że cel akcji wydaje się

\footnotetext{
${ }^{66}$ B. Śliwerski, Diagnoza uspołecznienia publicznego szkolnictwa III RP, s. 180-202.

${ }^{67}$ Zob. V. Kopińska, Wspótczesne problem samorzadności uczniowskiej, [w:] Opieka o wychowanie - tradycja i problemy wspótczesne, red. D. Apanel, Kraków 2009.

${ }^{68}$ Zob. R. Szczepanik, Kształcenie do życia w społeczeństwie demokratycznym, [w:] Podręczniki i poradniki. Konteksty. Dyskursy. Perspektywy, red. M. Chomczyńska-Rubacha, Kraków 2011.

${ }^{69}$ Por. International Civic and Citizenship Study, 2009.

${ }^{70}$ B. Kubiczek, Projekt „Szkoła Demokracji - Szkoła Samorząności”, s. 20.

71 Tamże.
} 
słuszny, to symulacja wyborów jest kolejnym działaniem pozornym, bowiem uczniowie w codzienności szkolnej najczęściej nie mają wpływu na decyzje podejmowane przez władze szkoły, władze samorządowe, czy parlamentarne. Zwraca na to uwagę Śliwerski, pisząc

skupiono się zatem bardziej na tym, by uczniowie wzmacniali $\mathrm{w}$ sobie i szanowali wzajemnie postawy obywatelskie, mając możliwość wyrażania jedynie $\mathrm{w}$ formie zabawy [podkreśl. DH-G] własnej opinii na temat ubiegających się o realną władzę samorządową czy parlamentarną partii politycznych, niż na budowaniu wraz z uczniami i ich rodzicami rzeczywistej, możliwej prawnie platformy do współpracy i współdecydowania o realnych sprawach ich środowisk i szkoły, np. w formie laboratoryjnego symulowania prac rad szkoły, by tym samym przygotować ich do wspólnego powołania tego organu ${ }^{72}$.

W tej sytuacji polska szkoła nie jest ani demokratyczna, ani obywatelska, jest hierarchiczna i scentralizowana, rzadko respektująca prawa obywatelskie uczniów. Co więcej, kwestie wyborów i procesu głosowania w szkole rozumiane są jako przygotowanie uczniów do udziału w wyborach politycznych, a zatem zaangażowanie obywatelskie zostaje najczęściej zredukowane do konwencjonalnej działalności. Potwierdza to również zawartość dotychczasowych podstaw programowych wiedzy o społeczeństwie ${ }^{73}$. Pomija się inne aspekty angażowania się uczniów w społeczność szkolną, które są podstawowym ogniwem kształtowania aktywnego obywatelstwa. Warto w tym miejscu odwołać się do spostrzeżeń Marii Czerepaniak-Walczak, która zauważa, że szkoła

zwykle postrzegana jest jako środowisko doświadczania zaangażowania $\mathrm{w}$ pracę samorządu uczniowskiego i zdarzenia o charakterze odświętnym (jak uroczystości szkolne i państwowe), podczas gdy rzeczywistym źródłem doświadczeń społecznych i obywatelskich są codzienne zdarzenia związane z uczeniem się, życiem zespołów klasowych $^{74}$.

72 B. Śliwerski, Diagnoza uspołecznienia publicznego szkolnictwa III RP, s. 54.

${ }^{73}$ Por. Rozporządzenie Ministra Edukacji Narodowej i Sportu z 26 lutego 2002 r. w sprawie podstawy programowej wychowania przedszkolnego oraz kształcenia ogólnego w poszczególnych typach szkół; Rozporządzenie Ministra Edukacji Narodowej z 23 grudnia 2008 r. w sprawie podstawy programowej wychowania przedszkolnego oraz kształcenia ogólnego w poszczególnych typach szkól; Rozporządzenie Ministra Edukacji Narodowej z 14 lutego 2017 r. $\mathrm{w}$ sprawie podstawy programowej wychowania przedszkolnego oraz podstawy programowej kształcenia ogólnego dla szkoły podstawowej, w tym dla uczniów z niepełnosprawnością intelektualną w stopniu umiarkowanym lub znacznym, kształcenia ogólnego dla branżowej szkoły I stopnia, kształcenia ogólnego dla szkoły specjalnej przysposabiającej do pracy oraz kształcenia ogólnego dla szkoły policealnej.

${ }_{74} \mathrm{M}$. Czerepaniak-Walczak, Zaangażowanie w szkole - szkoła zaangażowania. O możliwościach i utrudnieniach demokratycznego uczestniczenia uczniów w sferze publicznej, Studia Edukacyjne, 2012, 22, s. 143. 
Autorzy Raportu z badań przeprowadzonych pod kierownictwem Marii Dudzikowej, dotyczącym kapitału społecznego młodzieży wskazują, że uczniowie nie typowali lekcji wychowawczych jako tych, na których poruszało się problematykę społeczną i obywatelską ${ }^{75}$. Ponadto, wyniki ich badań pokazują niski poziom społecznego zaangażowania młodych ludzi w rozumieniu zarówno konwencjonalnym (udział w wyborach), jak i niekonwencjonalnym (działalność w różnych organizacjach) ${ }^{76}$. Wyniki te wpisują się w trend "społecznego bezruchu” polskiego społeczeństwa, którego głównym motorem wydaje się szkoła.

Warto jednak, jak sądzę, przywołać paradoks polskiej edukacji obywatelskiej, polegający na tym, że chociaż polscy uczniowie wykazują niski stopień demokratyzacji i aktywności obywatelskiej, to posiadają wysoki stopień wiedzy obywatelskiej. Pokazuje to zatem, że założenia podstaw programowych, w których cele nakierowane są na przekazywanie wiedzy, są właściwie realizowane. Oto bowiem 14-latkowie biorący udział w badaniu CIVED w 1999 roku zajęli pierwsze miejsce pod względem wiedzy obywatelskiej z 28 uczestniczących w nim państw. Bardzo dobre wyniki uzyskali również polscy 14-latkowie w International Civic and Citizenship Education Study (ICCS) z 2009 roku, przeprowadzonych w 38 krajach świata (w tym również w porównywanej w niniejszej pracy Anglii), zajmując szósty wynik na świecie ${ }^{77}$. Anna Wiłkomirska zwraca jednak uwagę, że test ten odsłonił braki wiedzy o demokracji i zasadach jej funkcjonowania oraz na nieznajomość podstaw prawa ${ }^{78}$. Ujawiony został również wyraźny deficyt w zakresie myślenia krytycznego ${ }^{79}$, które jako kluczowa kompetencja jest marginalizowane $w$ podstawach programowych wiedzy o społeczeństwie.

Z tej perspektywy polscy uczniowie charakteryzują się wysokim stopniem wiedzy o demokracji (co wpisuje się w stosowany model oparty na dydaktyzmie i encyklopedyzmie), natomiast gorzej niż ich rówieśnicy z innych krajów są gotowi do mierzenia się z problemami demokracji. Ponadto, przywołane badania pokazały silną korelację między wysokimi wynikami uczniów w teście a wysokim kapitałem społeczno-kulturowym (a zatem, czynnik związany z domem rodzinnym). W tym kontekście Anna Wiłkomirska zauważa:

${ }^{75}$ Zob. M. Dudzikowa i in., Kapitał społecznych w szkołach różnego szczebla. Diagnoza i uwarunkowania, Kraków 2011, s. 159.

${ }^{76}$ M. Dudzikowa i in., Oblicza kapitaty społecznego uniwersytetu. Diagnoza - interpretacje konteksty, Kraków 2011, s. 111.

77 Szczegółowa metodologia i organizacja badań została przedstawiona w: A. Wiłkomirska, Wiedzieć i rozumieć, aby być obywatelem. Studium empiryczne, Warszawa 2013.

${ }^{78}$ Tamże, s. 126.

79 Tamże, s. 128. 
szkoła ciągle ma wiele do zrobienia zarówno w procesie wyrównywania szans, jak i organizowaniu oraz wspieraniu na swoim terenie działań, które nie tylko dadzą młodzieży szanse praktykowania demokracji i obywatelstwa, ale również pokażą siłę i skuteczność działań grupowych ${ }^{80}$.

Analizując sondaże opinii publicznej, wyniki raportów, których uczestnikiem jest młodzież oraz liczne badania dotyczące społecznej i obywatelskiej aktywności młodych ludzi, nadal nie napawają one optymizmem. Szkolna edukacja obywatelska - w praktyce - najczęściej jest realizowana w ramach przedmiotu wiedzy o społeczeństwie, a więc jak sama nazwa wskazuje, zorientowana jest $\mathrm{w}$ głównej mierze na sferę poznawczą. W efekcie daje to wysokie osiągnięcia polskiej młodzieży w międzynarodowych testach wiedzy. Znacznie gorzej wygląda kształtowanie umiejętności aktywnego, zaangażowanego i odpowiedzialnego obywatelstwa. Edukacja obywatelska w szkole - zarówno w wymiarze przedmiotowym, jak i ogólnoszkolnym - przypomina bardziej uczenie się ",o" edukacji obywatelskiej, "o" demokracji, "o" społeczeństwie obywatelskim, "o" zaangażowaniu, akcentując w mniejszym stopniu kształcenie „dla”.

\section{Podsumowanie}

Wydaje się, że istotna z punktu widzenia tworzenia społeczeństwa obywatelskiego, budowania wysokiego kapitału społecznego i zaufania społecznego jest edukacja obywatelska. Placówki oświatowe, a zwłaszcza szkoły stają się miejscem, w którym nie tylko przekazywana jest wiedza o obywatelstwie, ale także budowany jest odpowiedni klimat do kształtowania postaw obywatelskich. Z tej perspektywy ważne staje się również określenie celów kształcenia obywatelskiego oraz określenie wzoru obywatelstwa, do którego wychowane i socjalizowane jest przyszłe pokolenie. Przykład edukacji obywatelskiej w Anglii - mimo że niewolny od krytyki - pokazuje, że systemowe rozwiązania, poprzedzone diagnozą w zakresie potrzeb i wyzwań społecznych, określenie celów kształcenia obywatelskiego, ich implementacja i monitoring do pewnego stopnia przynoszą korzystny efekt. Wyrażony jest on stabilnym i wysokim poziomem zaufania społecznego oraz tendencją wzrostową w podejmowaniu przez młodych ludzi aktywności obywatelskiej i społecznej.

Trzeba podkreślić, odwołując się zarówno do teorii i praktyki społecznej, że poziom kapitału i zaufania społecznego w dużym stopniu zależy od wykształcenia społeczeństwa. Nie można jednak zapominać, iż na ich kształt

${ }^{80}$ Tamże, s. 171. 
wpływają również inne, pozaszkolne czynniki, a w przypadku Polski duże znaczenie mają uwarunkowania historyczne. Niemniej jednak od trzydziestu lat pisana jest nowa historia, wolnej i demokratycznej Polski, w której mimo wielu pesymistycznych diagnoz, powoli rodzi się społeczeństwo obywatelskie. Niewątpliwym problemem nadal pozostaje niski stopień zaufania społecznego. Sytuacja społeczeństwa ryzyka, kultury strachu nie sprzyja budowaniu zaufania ${ }^{81}$. A to z kolei może wpływać na niski stopień zaangażowania społecznego. Należy też zauważyć, iż młodzież szkolna traktowana jest w kategoriach przyszłych obywateli. Podmiotowość obywatelską, a zatem poczucie sprawczości, można kształtować od najmłodszych lat, traktując młodego człowieka jako obywatela, a nie „półobywatela”. Ponadto, szkoła jako pierwsze i główne ogniwo społeczeństwa obywatelskiego może być miejscem, w którym żyje i tworzy wspólnota lokalna. Takie podejście do szkoły sprawia, że jej zadanie polega na integrowaniu środowiska lokalnego, jednak by $\mathrm{w}$ pełni realizować to zadanie, musiałaby być ona $\mathrm{w}$ pełni demokratyczna i uspołeczniona. Do tej przemiany niepotrzebne są jedynie reformy polityczne i strukturalne, lecz transformacja w sposobie postrzegania szkoły i jej społecznych więzi z najbliższym otoczeniem.

Jako że głównym czynnikiem kształtującym postawy aktywnego i zaangażowanego obywatelstwa jest wysoki kapitał społeczny, a ten z kolei w głównej mierze powiązany jest z pierwotną agendą socjalizacyjną, czyli rodziną, w różnych dokumentach strategicznych zaleca się, aby system szkolny działał na rzecz dzieci i młodzieży o niższym kapitale społecznym. Jednak budowanie kapitału społecznego oraz powiązanego z nim silnie społecznego zaufania, wymaga - podkreślę raz jeszcze - otwartego i demokratycznego klimatu. $W$ przeciwnym razie - $\mathrm{w}$ dzisiejszej, często złożonej rzeczywistości - młody człowiek może wybrać drogi, które ułatwią mu jej zrozumienie, na przykład schematyczne i uproszczone widzenie świata, podatność na manipulację, manifestowanie postaw ksenofobicznych oraz afirmację dla agresywnego nacjonalizmu i szowinizmu, eskapizm od wolności na rzecz uwodzącej dyktatury i zniewolenia.

\section{BIBLIOGRAFIA}

Aktywność społeczna Polaków - poziom zaangażowania i motywacje - Raport z badań, Maj 2011, adres internetowy: http://erw2011.gov.pl/static/upload/komunikat-1.pdf, [dostęp: 20.04.2012].

Beck J., A brief history of citizenship education in England and Wales, [w:] Debates in citizenship education, red. J. Arthur, H. Cremin, Routledge, London - New York 2012.

Bourdieu P., Reprodukcja, Wydawnictwo Naukowe PWN, Warszawa 2012.

${ }^{81}$ Por. m.in. F. Furedi, Culture of fear, London - New York 2006. 
Brett P., Identity and Diversity: Citizenship Education and Looking Forwards from the Ajegbo Report, 2007, http:/ / www.citized.info/pdf/commarticles/Peter\%20Brett\%20\%20Identity\%20and\%20Diversity.pdf [dostęp: 21.03.2017].

Bukowska X., Wnuk-Lipiński E., Obywatelskość a la polonaise - czyli jakimi obywatelami sa Polacy? Nauka, 2009, 1.

CBOS, Aktywność Polaków w organizacjach obywatelskich, Komunikat z badań nr 13/2016, Centrum Badania Opinii Społecznej CBOS, Warszawa 2016.

CBOS, Zaufanie społeczne, Komunikat z badań nr 18/2016, adres internetowy: https:/ / www.cbos.pl/SPISKOM.POL/2016/K_018_16.PDF, [dostęp: 1.12.2019]

Citizenship Survey 2008-09, adres internetowy: https://webarchive.nationalarchives. gov.uk/20120919213933/http://www.communities.gov.uk/documents/statistics/ pdf/1284311.pdf [dostęp: 1.12.2019]

Czapiński J., Panek T., Diagnoza społeczna 2015. Warunki i jakość życia Polaków, Rada Monitoringu Społecznego, Warszawa 2015.

Czerepaniak-Walczak M., Zaangażowanie w szkole - szkoła zaangażowania. O możliwościach i utrudnieniach demokratycznego uczestniczenia uczniów w sferze publicznej, Studia Edukacyjne, 2012, 22.

De Tocqueville A., O demokracji w Ameryce, Wydawnictwo Aletheia, Warszawa 2005.

Dudzikowa M., Erozja kapitału społecznego w szkole w atmosferze nieufności, [w:] Kapitat społecznych w szkołach różnego szczebla. Diagnoza i uwarunkowania, Oficyna Wydawnicza Impuls, Kraków 2011.

Dudzikowa M. i in., Kapitał społeczny w szkołach różnego szczebla. Diagnoza i uwarunkowania, Oficyna Wydawnicza Impuls, Kraków 2011.

Dudzikowa M. i in., Oblicza kapitały społecznego uniwersytetu. Diagnoza - interpretacje - konteksty, Oficyna Wydawnicza Impuls, Kraków 2011.

Durkheim E., O podziale pracy spotecznej, Wydawnictwo Naukowe PWN, Warszawa 2019.

Furedi F., Culture of fear, Continuum International Publishing Group, London - New York 2006.

Halpern D., Social capital, Polity Press, Cambridge 2014.

Hejwosz-Gromkowska D., Edukacja obywatelska we współczesnej Anglii. Studium socjopedagogiczne, Wydawnictwo Naukowe UAM, Poznań 2019.

House of Commons, General Election 2019: full results and analysis, adres internetowy: https:// researchbriefings.parliament.uk/ResearchBriefing/Summary/CBP-8749, [dostęp: 2.01.2020].

Keating A. i in., Citizenship education in England 2001-2010: young people's practices and prospects for the future: the eighth and final report from the Citizenship Education Longitudinal Study (CELS), Department for Education 2011.

Keating A., Green A., Janmaat G., Young Adults and Politics Today: disengaged and disaffected or engaged and enraged?: The latest findings from the Citizenship Education Longitudinal Study (CELS), Working Paper 2015, adres strony: http://eprints.ioe.ac.uk/21838/, [dostęp: 11.11.2017].

Keating A., Kerr D., Putting participation into practice: re-evaluating the implementation of the Citizenship curriculum in England, [w:] Education for Civic and Political Participation: A Critical Approach, red. R. Hedtke, T. Zimenkova, Routledge, London 2013.

Kerr D., Smith A., Twine C., Citizenship education in the United Kingdom, [w:] Education for citizenship and democracy, red. J. Arthur, I. Davies, C. Hahn, Sage, London 2008.

Kinowska Z., Kondycja społeczeństwa obywatelskiego w Polsce, INFOS, Biuro Analiz Sejmowych, nr 22, 2012. 
Kopińska V., Wspótczesne problemy samorzadności uczniowskiej, [w:] Opieka i wychowanie tradycja i problemy współczesne, red. D. Apanel, Oficyna Wydawnicza Impuls, Kraków 2009.

Kopińska V., Edukacja obywatelska. Krytyczna analiza dyskursu podręczników szkolnych, Wydawnictwo Naukowe Uniwersytetu Mikołaja Kopernika, Torun 2017.

Krajowe Biuro Wyborcze, Wybory do Sejmu i Senatu Rzeczpospolitej Polskie 2019, adres internetowy: www.wybory.gov.pl [dostęp: 2.12.2019].

Kubiczek B., Projekt „Szkoła Demokracji - Szkoła Samorządności”. Kompetencje społeczne i obywatelskie uczniów i nauczycieli. Materiaty dla uczestnika Konferencji, Sosnowiecke Centrum Edukacji „Edukator", Sosnowiec 2012.

Kymlicka W., Contemporary political philosophy. An Introduction, Oxford University Press, Oxford 2002.

Li Y., Smith N., Dangerfield P., Social trust. The impact of social networks and inequality, British Social Attitudes, 2017, 35.

Lopez H., Kiesa A., What we know about civic engagement among college students, [w:] Civic engagement in higher education. Concepts and practices, red. B. Jacoby and Associates, Jossey-Bass, San Francisco 2009.

Malik A., Citizenship education, race and community cohesion, [w:] Debates in citizenship education, red. J. Arthur, H. Cremin, Routledge, London - New York 2012.

McTighe Musil C., Educating students for personal and social responsibility, [w:] Civic engagement in higher education. Concepts and practices, red. B. Jacoby and Associates, Jossey-Bass, San Francisco 2009.

Olech A., Między zainteresowaniem a zaangażowaniem - aktywność obywatelska i organizacje pozarzadowe w Polsce, Analizy i Opinie, Numer specjalny, 2014, 7.

Petersen A., Where now for citizenship education? [w:] Debates in citizenship education, red. J. Arthur, H. Cremin, Routledge, London - New York 2012.

Putnam R.D., Bowling alone. The collapse and revival of American community, Simon \& Schuster Paperbacks, New York 2000.

Putnam R.D., Community based social capital and educational performance, [w:] Making good citizens. Education and civil society, red. D. Ravitch, J.P. Viteritti, Yale University Press, New Haven - London 2001.

Przyszczypkowski K., Edukacja dla demokracji. Strategie zmian a kompetencje obywatelskie, Wydawnictwo Edytor, Poznań - Torun 1999.

Rozporządzenie Ministra Edukacji Narodowej i Sportu z 26 lutego 2002 r. w sprawie podstawy programowej wychowania przedszkolnego oraz kształcenia ogólnego w poszczególnych typach szkół.

Rozporządzenie Ministra Edukacji Narodowej z 23 grudnia 2008 r. w sprawie podstawy programowej wychowania przedszkolnego oraz kształcenia ogólnego w poszczególnych typach szkół.

Rozporządzenie Ministra Edukacji Narodowej z 14 lutego 2017 r. w sprawie podstawy programowej wychowania przedszkolnego oraz podstawy programowej kształcenia ogólnego dla szkoły podstawowej, w tym dla uczniów z niepełnosprawnością intelektualną w stopniu umiarkowanym lub znacznym, kształcenia ogólnego dla branżowej szkoły I stopnia, kształcenia ogólnego dla szkoły specjalnej przysposabiającej do pracy oraz kształcenia ogólnego dla szkoły policealnej.

Szczurek-Boruta A., Stałość i zmienność. Poczucie tożsamości narodowej młodzieży i nowy wymiar edukacji obywatelskiej, [w:] Etniczność i obywatelskość w nowej Europie. Konteksty edukacji międzykulturowej, red. J. Nikitorowicz, D. Misiejuk, M. Sobecki, Wydawnictwo Uniwersyteckie Trans Humana, Białystok 2007. 
Solarczyk-Szwec H., Kopińska V., Matusiak A., Kompetencje społeczne na wejściu w dorosłość. Krytyczna analiza podstawy programowej kształcenia ogólnego dla IV etapu edukacyjnego, Edukacja Dorosłych, 2016, 2.

Sturman L. i in., Citizens in Transition - Civic Engagement and Political Participation among Young People 2001-2011, Economic and Social Research Council (ESRC), National Foundation for Educational Research (NFER), 2012.

Szczepanik R., Kształcenie do życia w społeczeństwie demokratycznym, [w:] Podręczniki i poradniki. Konteksty. Dyskursy. Perspektywy, red. M. Chomczyńska-Rubacha, Oficyna Wydawnicza Impuls, Kraków 2011.

Śliwerski B., Diagnoza uspołecznienia publicznego szkolnictwa III RP. W gorsecie centralizmu, Oficyna Wydawnicza Impuls, Kraków 2013.

Wiłkomirska A., Wiedzieć i rozumieć, aby być obywatelem. Studium empiryczne, Wydawnictwa Uniwersytetu Warszawskiego, Warszawa 2013.

Wnuk-Lipiński E., Socjologia życia publicznego, Wydawnictwo Naukowe Scholar, Warszawa 2008. 